Article

\title{
Phenolic Compounds from Allium schoenoprasum, Tragopogon pratensis and Rumex acetosa and Their Antiproliferative Effects
}

\author{
Zdenka Kucekova $^{1}$, Jiri Mlcek ${ }^{2}$, Petr Humpolicek ${ }^{1,3, *}$, Otakar Rop ${ }^{2}$, Pavel Valasek ${ }^{3}$ and \\ Petr Saha $^{3}$
}

1 Polymer Centre, Faculty of Technology, Tomas Bata University at Zlin, T.G.M. sq. 275, 762 72, Zlin, Czech Republic; E-Mail: kucekova@ft.utb.cz (Z.K.)

2 Department of Food Technology and Microbiology, Faculty of Technology, Tomas Bata University at Zlin, T.G.M. sq. 275, 76272 Zlin, Czech Republic; E-Mails: mlcek@ft.utb.cz (J.M.); rop@ft.utb.cz (O.R.)

3 Centre for Polymer Systems, Polymer Centre, Tomas Bata University at Zlin, T.G.M. sq. 5555, 76005 Zlin, Czech Republic; E-Mails: valasek@ft.utb.cz (P.V.); saha@utb.cz (P.S.)

* Author to whom correspondence should be addressed; E-Mail: humpolicek@ uni.utb.cz; Tel.: +420-576-038-035; Fax: +420-576-031-444.

Received: 29 August 2011; in revised form: 21 October 2011 / Accepted: 26 October 2011 / Published: 3 November 2011

\begin{abstract}
Experimental studies have shown that phenolic compounds have antiproliferative and tumour arresting effects. The aim of this original study was to investigate the content of phenolic compounds $(\mathrm{PhC})$ in flowers of Allium schoenoprasum (chive), Tragopogon pratensis (meadow salsify) and Rumex acetosa (common sorrel) and their effect on proliferation of $\mathrm{HaCaT}$ cells. Antiproliferative effects were evaluated in vitro using the following concentrations of phenolic compounds in cultivation medium: 100, 75, 50 and $25 \mu \mathrm{g} / \mathrm{mL}$. Phenolic composition was also determined by HPLC. The results indicate that even low concentrations of these flowers' phenolic compounds inhibited cell proliferation significantly and the possible use of the studied herb's flowers as sources of active phenolic compounds for human nutrition.
\end{abstract}

Keywords: Allium schoenoprasum; Tragopogon pratensis; Rumex acetosa; proliferation; phenolic compounds; HaCaT 


\section{Introduction}

Phenolic compounds ( $\mathrm{PhC})$ and their anti-tumour effects have been studied for many years [1]. Grape seeds and skins [2], tea [3] or fruits [4,5] are considered to be rich on these phytochemicals. Every plant not only has different concentrations of $\mathrm{PhC}$, but their composition and content in every part is different [6]. Researchers' attention in terms of effects on tumour diseases has been mostly focused on wine $\mathrm{PhC}$ [7] or tea $\mathrm{PhC}$ [8], but the effect of herb flowers, which are also good source of phytochemicals [9], has not been described yet. In the present study the plants Allium schoenoprasum (chive) Rumex acetosa (common sorrel) and Tragopogon pratensis (meadow salsify) which could be easily available sources of $\mathrm{PhC}$ in Europe were studied for the first time in the context of their potential anti-tumour effects.

$\mathrm{PhC}$ constitute a heterogeneous class of compounds [10] with varied protective effects $[3,11]$. PhC have been reported to display a variety of biological actions. They can act as antioxidants [12], antiangiogenics [13], selective estrogen receptor modifiers [14], anti-carcinogenic and anti-inflammatory agents [15] and many others. The most significant properties of $\mathrm{PhC}$ that may affect carcinogenesis are trapping of ultimate carcinogens [16], inhibitory action against nitrosation reactions [6], inhibition of cell proliferation-related activities [17], induction of cell apoptosis [16], cell cycle arrest [18], blockade of mitotic signal transduction through modulation of growth factor receptor binding [16], nuclear oncogene expression [19], inhibition of DNA synthesis [20] and modulation of signal transduction pathways by altered expression of key enzymes such as cyclooxygenases and protein kinases [21]. The aim of this study is to determine the effect of $\mathrm{PhC}$ contained in the flowers of three herb species on cell proliferation and to demonstrate the suitability of this herbs for the prevention of tumour diseases.

\section{Results and Discussion}

Several hundred different $\mathrm{PhC}$ have been identified in plants [22]. In this study the following ten PhC were detected by HPLC: gallic acid (GA), coumaric acid (CA), ferulic acid (FA), rutin (Ru), resveratrol (Re), vanillic acid (VA), sinapic acid (SA), catechin $(\mathbf{C})$, quercetin, caffeic acid $(\mathbf{C A})$ and cinnamic acid. The herb flowers used in this study (A. schoenoprasum, T. pratensis and R. acetosa) did not contain all of these PhC. Although quercetin is one of the most common flavonoids in plants, it was not detected in any of the studied herbs. No cinnamic acid was found either.

The content of $\mathrm{PhC}$ in dry matter of the studied herb flowers is shown in Table 1. A. schoenoprasum contains GA $(201.76 \mu \mathrm{g} / \mathrm{g})$, CA $(207.29 \mu \mathrm{g} / \mathrm{g})$, FA $(887.44 \mu \mathrm{g} / \mathrm{g})$ and Ru $(20.26 \mu \mathrm{g} / \mathrm{g})$. Most types of PhC were determined in $T$. pratensis. These were GA $(1347.85 \mu \mathrm{g} / \mathrm{g}), \mathbf{F A}(197.79 \mu \mathrm{g} / \mathrm{g})$, Ru $(89.99 \mu \mathrm{g} / \mathrm{g}), \mathbf{R e}(13.95 \mu \mathrm{g} / \mathrm{g}), \mathbf{S A}(110.85 \mu \mathrm{g} / \mathrm{g})$ and CA $(278.72 \mu \mathrm{g} / \mathrm{g})$. In R. acetosa four kinds of PhC were found: $\operatorname{Re}(41.27 \mu \mathrm{g} / \mathrm{g}), \mathbf{V A}(130.29 \mu \mathrm{g} / \mathrm{g}), \mathbf{S A}(5708.48 \mu \mathrm{g} / \mathrm{g})$ and $\mathbf{C}(75.46 \mu \mathrm{g} / \mathrm{g})$.

In this study $\mathrm{HaCaT}$ cells were used to determine antiproliferative activity. As can be seen from Table 2, cells incubated in the presence of extracts have remarkable lower proliferation compared with control. These differences are statistically significant (Table 2). 
Table 1. Content of phenolic compounds in herbs.

\begin{tabular}{llcccccc}
\hline & & \multicolumn{2}{c}{ Allium schoenoprasum } & Tragopogon pratensis & \multicolumn{2}{c}{ Rumex acetosa } \\
\cline { 3 - 7 } PC & & $\begin{array}{c}\text { Extract } \\
(\boldsymbol{\mu g} / \mathbf{m L})\end{array}$ & $\begin{array}{c}\text { Dry matter } \\
(\boldsymbol{\mu g} / \mathbf{g})\end{array}$ & $\begin{array}{c}\text { Extract } \\
(\boldsymbol{\mu g} / \mathbf{m L})\end{array}$ & $\begin{array}{c}\text { Dry matter } \\
(\boldsymbol{\mu g} / \mathbf{g})\end{array}$ & $\begin{array}{c}\text { Extract } \\
(\boldsymbol{\mu g} / \mathbf{m L})\end{array}$ & $\begin{array}{c}\text { Dry matter } \\
(\boldsymbol{\mu g} / \mathbf{g})\end{array}$ \\
\hline GA & Gallic acid & 8.45 & 201.76 & 66.16 & 1347.85 & $/$ & $/$ \\
CA & Coumaric acid & 8.50 & 207.29 & $/$ & $/$ & $/$ & $/$ \\
FA & Ferulic acid & 37.16 & 887.44 & 9.71 & 197.79 & $/$ & $/$ \\
Ru & Rutin & 0.85 & 20.26 & 4.39 & 89.99 & $/$ & $/$ \\
Re & Resveratrol & $/$ & $/$ & 0.68 & 13.95 & 3.23 & 41.27 \\
VA & Vanillic acid & $/$ & $/$ & $/$ & $/$ & 11.03 & 130.29 \\
SA & Sinapic acid & $/$ & $/$ & 5.28 & 110.85 & 483.21 & 5708.48 \\
C & Catechin & $/$ & $/$ & $/$ & $/$ & 6.39 & 75.46 \\
CA & Caffeic acid & $/$ & $/$ & 13.68 & 278.72 & $/$ & $/$ \\
\hline
\end{tabular}

Table 2. Antiproliferation effect of different concentration of herb flowers' phenolic compounds on HaCaT cells quantified by a MTT assay (Average absorbance \pm SD).

\begin{tabular}{lc}
\hline Allium schoenoprasum $25 \mu \mathrm{g} / \mathrm{mL}$ & $0.1975 \pm 0.0128 * *$ \\
Allium schoenoprasum $50 \mu \mathrm{g} / \mathrm{mL}$ & $0.2043 \pm 0.0253 * *$ \\
Allium schoenoprasum $75 \mu \mathrm{g} / \mathrm{mL}$ & $0.2151 \pm 0.0164 * *$ \\
Allium schoenoprasum $100 \mu \mathrm{g} / \mathrm{mL}$ & $0.1930 \pm 0.0221 * *$ \\
Rumex acetosa $25 \mu \mathrm{g} / \mathrm{mL}$ & $0.5873 \pm 0.0671 * *$ \\
Rumex acetosa $50 \mu \mathrm{g} / \mathrm{mL}$ & $0.4472 \pm 0.0643 * *$ \\
Rumex acetosa $75 \mu \mathrm{g} / \mathrm{mL}$ & $0.2367 \pm 0.0578 * *$ \\
Rumex acetosa $100 \mu \mathrm{g} / \mathrm{mL}$ & $0.1903 \pm 0.0203 * *$ \\
Tragopogon pratensis $25 \mu \mathrm{g} / \mathrm{mL}$ & $0.4090 \pm 0.0216 * *$ \\
Tragopogon pratensis $50 \mu \mathrm{g} / \mathrm{mL}$ & $0.1991 \pm 0.0433 * *$ \\
Tragopogon pratensis $75 \mu \mathrm{g} / \mathrm{mL}$ & $0.1666 \pm 0.0104 * *$ \\
Tragopogon pratensis $100 \mu \mathrm{g} / \mathrm{mL}$ & $0.1738 \pm 0.0165 * *$ \\
Control & $0.8187 \pm 0.1806 *$ \\
\hline
\end{tabular}

Note: Values with different superscripts show significance level within column: $\mathrm{P}<0.01(*, * *)$.

Figure 1 shows the antiproliferation activity of $A$. schoenoprasum extracts The most abundant $\mathrm{PhC}$ in A. schoenoprasum was FA (Table 1), which is one of the most common phenolic acids in plants. For example, content of FA in lavender is $5.3 \mu \mathrm{g} / \mathrm{g}$ dry sample [23], in Crete oregano $3.4 \mu \mathrm{g} / \mathrm{g}$ dry sample and in mountain tea $69.5 \mu \mathrm{g} / \mathrm{g}$ dry sample [24]. FA has many biological activities like improvement of microcirculation, elimination of oxygen-free radicals, anti-inflammatory properties [25] and suppression of carcinogenesis [26]. According to Lin et al. [25], FA has the ability to inhibit cellular proliferation and tumour development, which matches our results. GA, CA and Ru were also detected in A. schoenoprasum, but their content was rather low. 
Figure 1. Antiproliferation activity of Allium schoenoprasum phenolic compounds on HaCaT cells (average \pm SD).

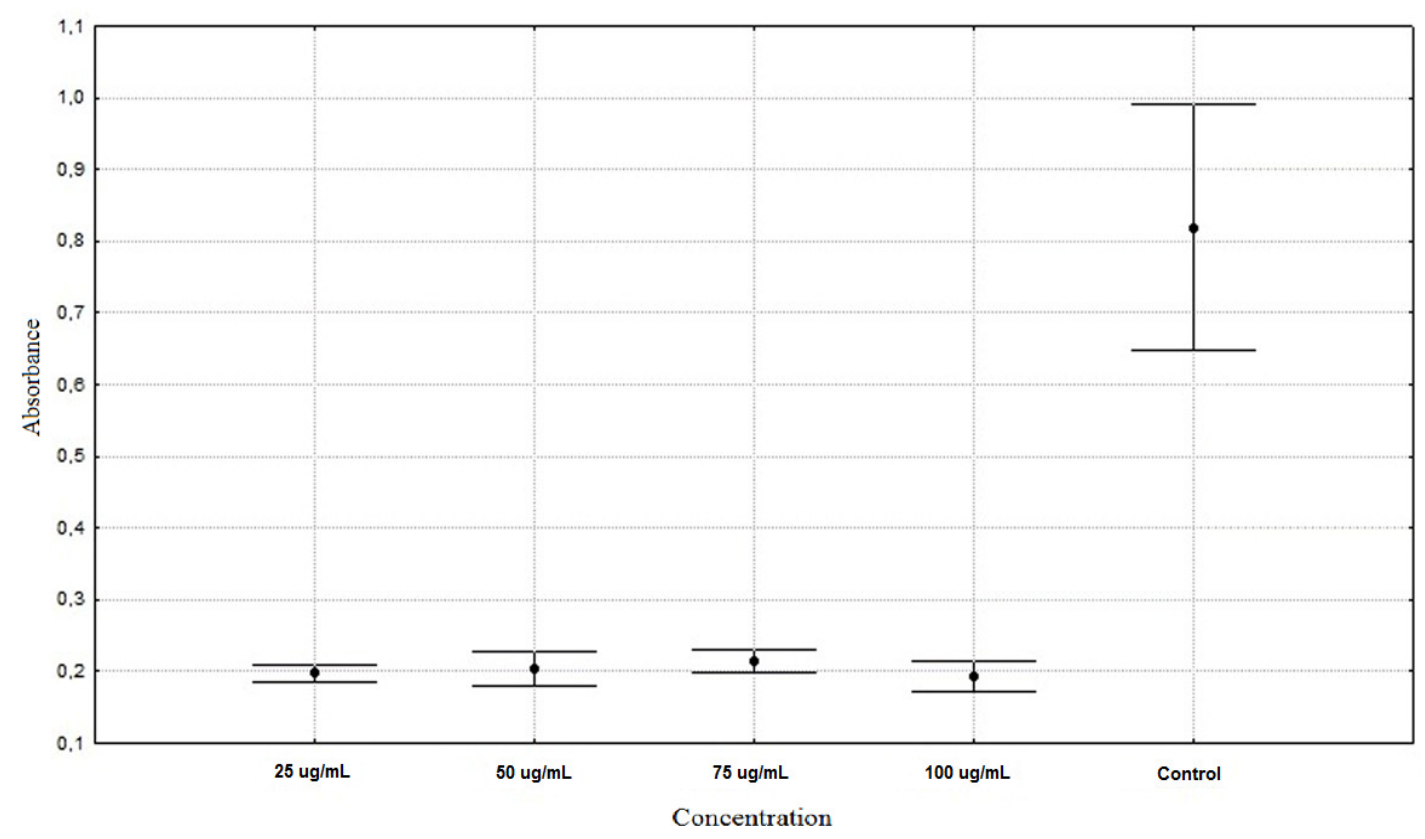

FA is also found in $T$. pratensis, but the content is nearly four times lower than in A. schoenoprasum. T. pratensis also contained GA, Ru, Re, SA and CA. The PhC of highest concentration in T. pratensis was found to be GA $(1,347.85 \mu \mathrm{g} / \mathrm{g})$. According to Proestos et al. [24] the content of GA is, for example, $15 \mu \mathrm{g} / \mathrm{g}$ dry sample in eucalyptus and $26 \mu \mathrm{g} / \mathrm{g}$ dry sample in mountain tea. GA is a free radical scavenger with significant inhibitory effects on cell proliferation, it induces apoptosis in a series of cancer cell lines, and shows selective cytotoxicity against tumour cells with higher sensitivity than normal cells [27,28].

Figure 2. Antiproliferation activity of Rumex acetosa phenolic compounds on HaCaT cells (average $\pm \mathrm{SD}$ ).

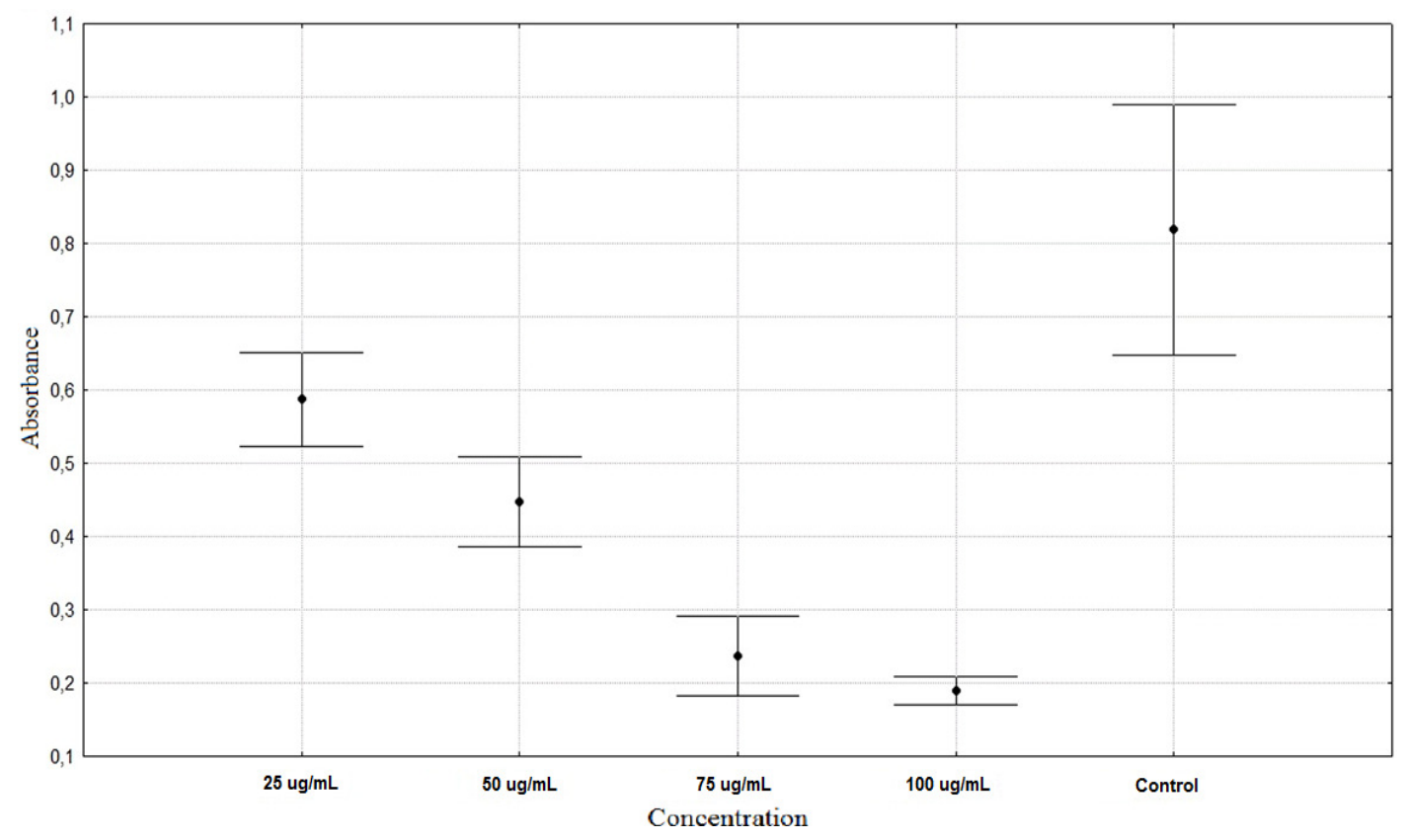


In contrast to $A$. schoenoprasum, extracts of $T$. pratensis and $R$. acetosa decreased the proliferation gradually. However the differences between each concentration and control were statistically significant in all cases (Table 2). R. acetosa shows similar antiproliferation activity at concentrations of 75 and $100 \mu \mathrm{g} / \mathrm{mL}$ (Figure 2). T. pratensis shows similar activity at $\mathrm{PhC}$ concentrations of 50, 75 and $100 \mu \mathrm{g} / \mathrm{mL}$ (Figure 3).

Figure 3. Antiproliferation activity of Tragopogon pratensis phenolic compounds on HaCaT cells (average \pm SD).

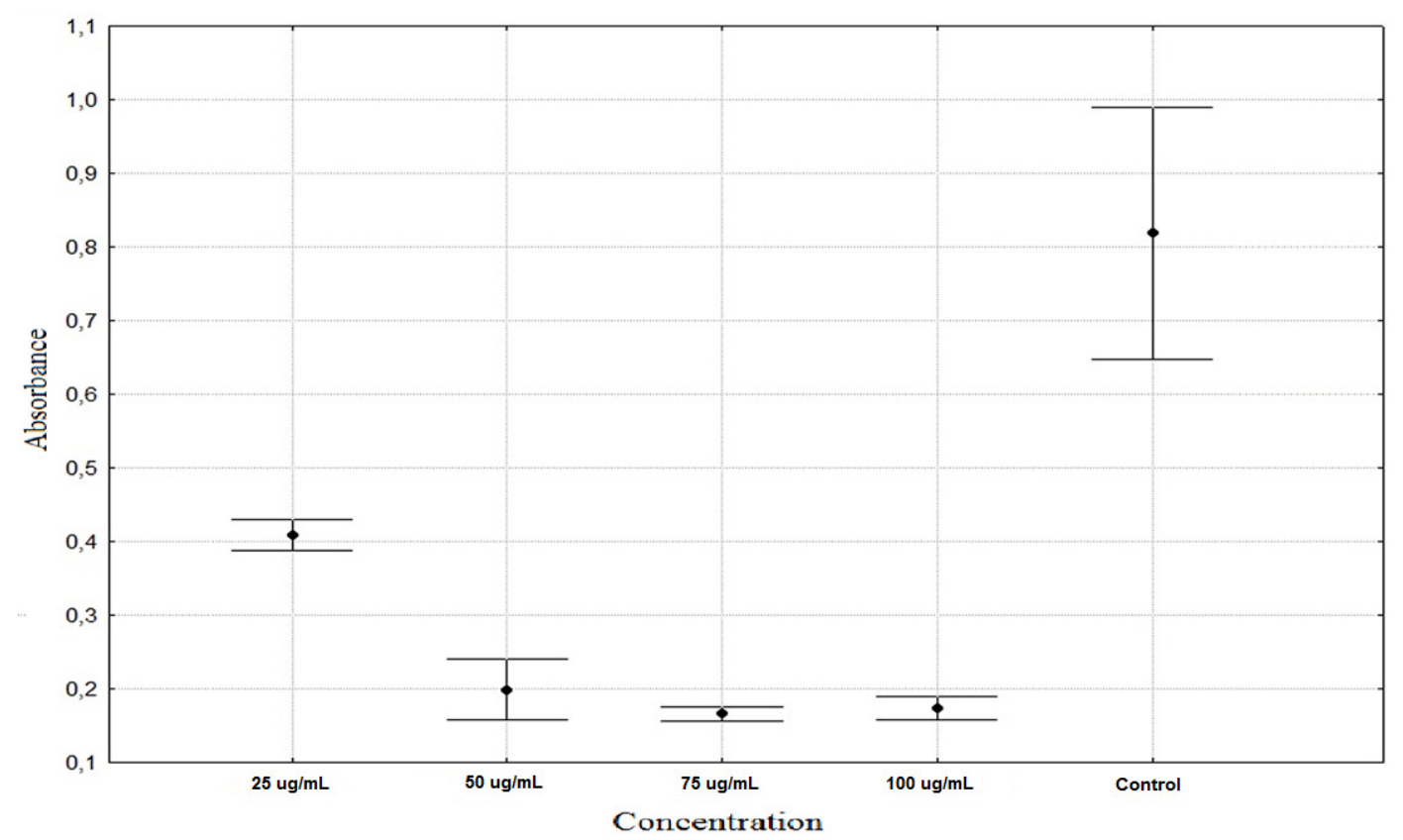

R. acetosa contained Re, VA, SA and C. The most abundant PhC was SA (5,708.48 $\mu \mathrm{g} / \mathrm{g})$. Extracts from $R$. acetosa had the lowest antiproliferation activity (Table 2), which can be caused by a phenomena described and explained by Kampa et al. [29] whereby the shortening of the side chain in SA leads to a loss of the antiproliferative activity.

$\mathrm{PhC}$ extracted from the herbs used for this study have higher antiproliferative activity in comparison with $\mathrm{PhC}$ used in other studies. For example, black tea $\mathrm{PhC}$ at a concentration of $100 \mu \mathrm{g} / \mathrm{mL}$ reduced cell viability by $60 \%$ [30]. Different camellia flower extracts at the same concentration decrease the cell viability in the range from 10 to $60 \%$ [31]. Results in this study reached values of about $80 \%$ decreased cell viability. These different results could be caused by different times of incubation and the use of different cell lines, which may be more toxicity resistant, as Murugan et al. [30] used HepG2 cells and Way et al. [31] used MCF-7 cells.

The observed antiproliferative activity of $\mathrm{PhC}$ can be explained by their modulation of different key targets of pathways controlling cell proliferation, differentiation, expression and cell death. The MAPK pathways can be used as example [32,33]. They include extracellular signal-regulated kinase (ERK), c-Jun Nterminal Kinase (JNK) and p38 MAPK [34]. According to Yeh and Yen [34] GA, which is present in $T$. pratensis and in A. schoenoprasum, increased the levels of phosphorylated JNK and p38 and almost completely blocked inhibition of the p38 MAPK pathway. T. pratensis and A. schoenoprasum also contain FA, which inhibits the activation of ERK [35]. JNK and p38 MAPK 
are also activated by $\mathbf{R e}$, indentified in $R$. acetosa and T. pratensis [33]. SA, present in very high amounts in $R$. acetosa and also found in T. pratensis, is involved in the MAPK pathways too [36]. Another signal molecule affected by $\mathrm{PhC}$ is Activator protein 1 (AP-1). For example, Re blocks AP-1-mediated gene expression [37]. GA and $\mathbf{C}$ inhibit AP-1 binding activity [38]. Other PhC like FA, SA and CA also have effects on AP-1 [36,39]. These PhC were present in every one of the three studied herb flowers.

Figure 4 shows differences between morphology of control [Figure 4(a)] and HaCaT cells incubated in the presence of A. schoenoprasum $\mathrm{PhC}$ [Figure 4(b)], R. acetosa extract [Figure 4(c)] and Tragopogon pratensis extract [Figure 4(d)] at a concentration of $75 \mu \mathrm{g} / \mathrm{mL}$, because at this concentration the differences in morphology are best illustrated.

Figure 4. (a) Control; (b) HaCaT cells incubated in presence of Allium schoenoprasum extract $(75 \mu \mathrm{g} / \mathrm{mL})$; (c) HaCaT cells incubated in presence of Rumex acetosa extract $(75 \mu \mathrm{g} / \mathrm{mL})$; (d) HaCaT cells incubated in presence of Tragopogon pratensis extract $(75 \mu \mathrm{g} / \mathrm{mL})$.

(a)

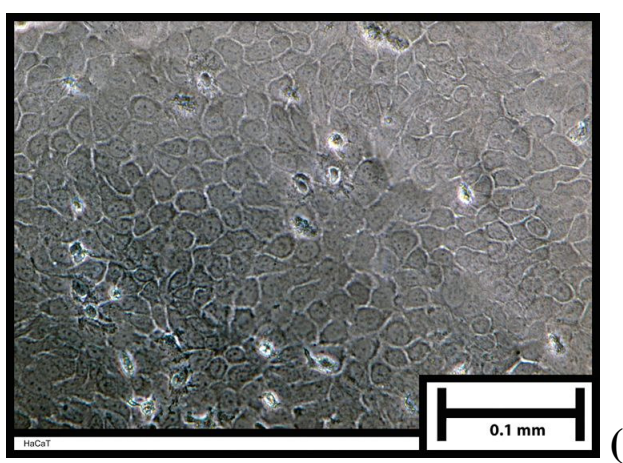

(b)

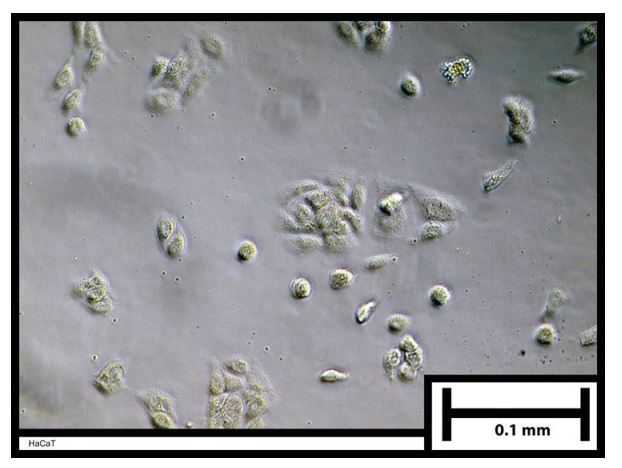

(c)

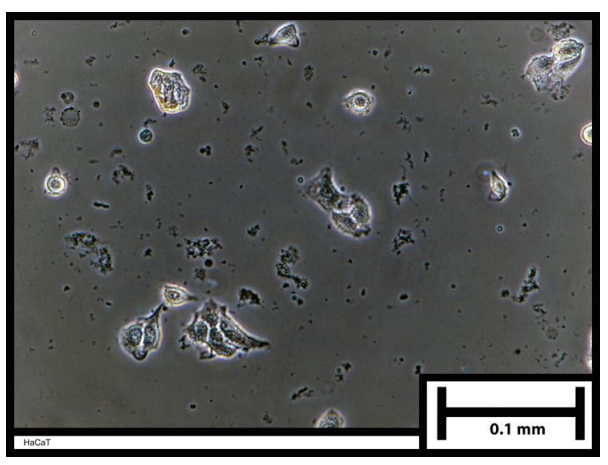

(d)

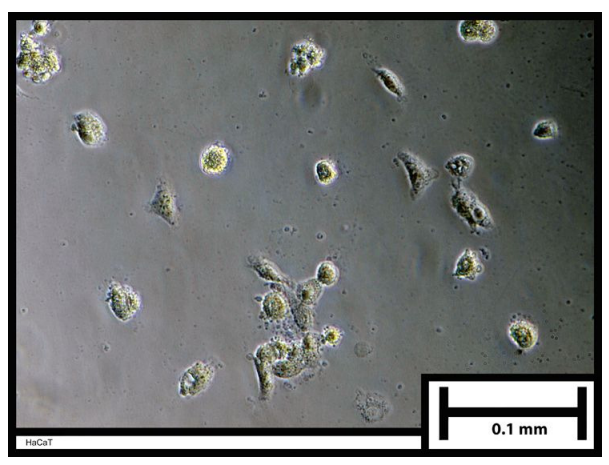

This study has demonstrated the impact of herbal flowers PhC on the proliferation of HaCaT cells. The antiproliferative activity depends on each particular herb. In the case of A. schoenoprasum the activity was independent of the applied concentration of $\mathrm{PhC}$, as similar activity was observed for all concentrations. The antiproliferative activity of $R$. acetosa and $T$. pratensis varied with the concentration of $\mathrm{PhC}$. In the case of $T$. pratensis, concentrations higher than $50 \mu \mathrm{g} / \mathrm{mL}$ do not have an significant impact on proliferation. In the case of $R$. acetosa, the critical concentration was found to be $75 \mu \mathrm{g} / \mathrm{mL}$. The different antiproliferative activities of herb extracts can be caused by variable $\mathrm{PhC}$ content and composition. Another factor which must be considered is the fact that this study only examined 10 types of polyphenols. 


\section{Experimental}

\subsection{Extraction Conditions}

$\mathrm{PhC}$ were extracted from flowers of Allium schoenoprasum, Rumex acetosa and Tragopogon pratensis. All flowers were cut during the year 2010 in the Czech Republic in central Europe. Immediately after cutting the flowers were frozen and stored at $-40{ }^{\circ} \mathrm{C}$. The extraction was performed according to Hakimuddin et al. [40] with some modifications: frozen herb flowers were homogenized in $90 \%$ methanol $(2 \mathrm{~mL} / \mathrm{g})$ and subsequently extracted at $4{ }^{\circ} \mathrm{C}$ for 30 minutes. After extraction centrifugation at $1,990 \mathrm{rpm}$ for 10 minutes was used to separate the supernatant. Sediments were subjected to a new extraction. This process was repeated three times. The methanol was removed using a Laborota 4011 digital rotary evaporator (Heidolph, Schwabach, Germany). Subsequently extracts concentration was adjusted to obtain concentration of $1,000 \mathrm{mg} / \mathrm{mL}$.

\subsection{Cell Cultivation}

The human immortalized non-tumorigenic keratinocyte cell line (HaCaT) [41] supplied by Cell Lines Service (Catalog No. 300493, Eppelheim, Germany) was used. Dulbecco's Modified Eagle Medium (DMEM) - high glucose, with added fetal bovine serum (10\%) and penicillin/streptomycin (100 U/mL) $(100 \mu \mathrm{g} / \mathrm{mL})$ (PAA Laboratories GmbH, Pasching, Austria) was used as the culture medium.

\subsection{Antiproliferation Test}

The $\mathrm{PhC}$ extracts were diluted in culture medium (DMEM) to obtain dilutions with concentrations of $100,75,50$ and $25 \mu \mathrm{g}$ of $\mathrm{PhC}$ per $\mathrm{mL}$ of cultivation medium. All dilutions were used immediately. Cells were pre-cultivated for $24 \mathrm{hrs}$ and the culture medium was subsequently replaced by dilutions. As a control experiment, pure medium without $\mathrm{PhC}$ was used. To assess antiproliferative activity on HaCaT cells, the MTT assay (Invitrogen Corporation, Carlsbad, California, USA) [42] was performed after three-day cultivation in dilutions. The absorbance was measured at $540 \mathrm{~nm}$ using a Sunrise microplate absorbance reader (Tecan, Männedorf, Switzerland). The cell proliferation expressed as MTT absorbance measured in respective dilutions relative to control is presented. All the tests were performed in quadruplicate. The photomicrographs were taken using an inverted Olympus CKX41 phase contrast microscope (Olympus, Hamburg, Germany). The differences between observed absorbance were detected by T-Test using Statistica for Windows.

\subsection{Determination of $P h C$}

A standard solution of tannin was prepared from tannin $(50 \mathrm{mg})$ dissolved in water $(100 \mathrm{~mL})$. The standard solution of tannin was added using a pipette to six $50 \mathrm{~mL}$ flasks in volumes of $0.2,0.3,0.4$, $0.5 \mathrm{~mL}$. Extract $(1 \mathrm{~mL})$ was added to the seven flasks and dissolved as needed. Distilled water $(20 \mathrm{~mL})$ and the Folin-Ciocalteu reagent $(1 \mathrm{~mL})$ was added to every flask. After three minutes $20 \%$ solution $\mathrm{Na}_{2} \mathrm{CO}_{3}(5 \mathrm{~mL})$ was added. The solutions were mixed and the distilled water was added to a volume of $50 \mathrm{~mL}$. After 30 minutes the color intensity compared to control (no tannin) was measured at $700 \mathrm{~nm}$. 


\subsection{Chromatography}

Determination of individual $\mathrm{PhC}$ was carried out using a Dionex UltiMate 3000 high performance liquid chromatography (HPLC) system (Dionex, Sunnyvale, California, USA). A Supelcosil LC-18-DB $(25 \mathrm{~cm} \times 4.6 \mathrm{~mm}$ I.D., $\mathrm{S}-5 \mu \mathrm{m})$ column was used. $\mathrm{PhC}$ were detected with DAD UV-Vis detection at $205 \mathrm{~nm}$. The mobile phases used for gradient HPLC elution were: (A) 5\% (v/v) acetonitrile, $0.035 \%(\mathrm{v} / \mathrm{v})$ trifluoroacetic acid and (B) $50 \%(\mathrm{v} / \mathrm{v})$ acetonitrile, $0.025 \%(\mathrm{v} / \mathrm{v})$ trifluoroacetic acid. The flow-rate was set at $1.0 \mathrm{~mL} / \mathrm{min}$. The gradient elution profile started with A-B (90:10), then B was gradually increased to $20 \%$ at $10 \mathrm{~min}$, to $40 \%$ at $16 \mathrm{~min}$, to $50 \%$ at $20 \mathrm{~min}$ and back to $40 \%$ from 25 to 27 min [43]. The data presented are the average values calculated from three measurements.

\section{Conclusions}

This study is the first study on the antiproliferation activity of chosen phenolic compounds contained in several herb flowers. The results in this study suggest that the tested herbs are a good source of phenolic compounds and that their concentration and composition varies with each species. The work presented proved that the phenolic compounds contained in medical herbs significantly decrease cell proliferation. The fact that natural phenolic compounds contained in herb flowers (A. schoenoprasum, T. pratensis and R. acetosa) inhibit cell proliferation makes those herb flowers potentially useful for the treatment and prevention of tumour diseases. The results suggest that antiproliferation activity does not depend exclusively on total phenolic compound content or composition, but it can be also influenced by other extracted active substances which were not detected.

\section{Acknowledgments}

This article was created with the support of Operational Program Research and Development for Innovations co-funded by the European Regional Development Fund (ERDF) and the national budget of the Czech Republic, within the framework of the Centre of Polymer Systems project (reg. number: CZ.1.05/2.1.00/03.0111). The work was also supported by a research project of the Ministry of Education, Youth and Sports of the Czech Republic (MSM 7088352101). Author Z. Kuceková thanks the internal grant of TBU at Zlin No. IGA/20/FT/11/D funded from the specific university research resources for support.

\section{References}

1. Katiyar, S.K.; Agarwal, R.; Mukhtar, H. Protective effects of green tea polyphenols administered by oral intubation against chemical carcinogen-induced forestomach and pulmonary neoplasia in A/J mice. Cancer Lett. 1993, 73, 167-172.

2. Sharif, T.; Auger, C.; Alhosin, M.; Ebel, C.; Achour, M.; Etienne-Selloum, N.; Fuhrmann, G.; Bronner, C.; Schini-Kerth, V.B. Red wine polyphenols cause growth inhibition and apoptosis in acute lymphoblastic leukaemia cells by inducing a redoxsensitive up-regulation of p73 and down-regulation of UHRF1. Eur. J. Cancer 2010, 46, 983-994. 
3. Luceri, C.; Caderni, G.; Sanna, A.; Dolara, P. Red Wine and Black Tea Polyphenols Modulate the Expression of Cycloxygenase-2, Inducible Nitric Oxide Synthase and Glutathione-Related Enzymes in Azoxymethane-Induced F344 Rat Colon Tumors. J. Nutr. 2002, 132, 1376-1379.

4. Iwasawa, H.; Morita, E.; Yui, S.; Yamazaki, M. Anti-oxidant Effects of Kiwi Fruit in Vitro and in Vivo. Biol. Pharm. Bull. 2011, 34, 128-134.

5. Rop, O.; Sochor, J.; Jurikova, T.; Zitka, O.; Skutkova, H.; Mlcek, J.; Salas, P.; Krska, B.; Babula, P.; Adam, V.; Kramarova, D.; Beklova, M.; Provaznik, I.; Kizek, R. Effect of five different stages of ripening on chemical compounds in medlar (Mespilus germanica L.). Molecules 2011, 16, 74-91.

6. Kuroda, Y.; Hara, Y. Antimutagenic and anticarcinogenic activity of tea polyphenols. Mutat. Res. 1999, 436, 69-97.

7. Castillo-Pichardo, L.; Martínez-Montemayor, M.M.; Martínez J.E.; Wall, K.M.; Cubano, L.A.; Dharmawardhane, S. Inhibition of mammary tumor growth and metastases to bone and liver by dietary grape polyphenols. Clin. Exp. Metastasis 2009, 26, 505-516.

8. Jin, H.; Tan, X.; Liu, X.; Ding, Y. The Study of Effect of Tea Polyphenols on Microsatellite Instability Colorectal Cancer and Its Molecular Mechanism. Int. J. Colorectal Dis. 2010, 25, 1407-1415.

9. Mlček, J.; Rop, O. Fresh edible flowers of ornamental plants-A new source of nutraceutical foods. Trends Food Sci. Tech. 2011, In Press.

10. Rop, O.; Mlček, J.; Juríková, T.; Valšíková, M.; Sochor, J.; Reznicek, V.; Kramarova, D. Phenolic content, antioxidant capacity, radical oxygen species scavenging and lipid peroxidation inhibiting activities of extracts of five black chokeberry (Aronia melanocarpa (Michx.) Elliot) cultivars. J. Med. Plants Res. 2010, 4, 2431-2437.

11. Walter, A.; Etienne-Selloum, N.; Sarr, M.; Kane, M.O.; Beretz, A.; Schini-Kerth, V.B. Angiotensin II induces the vascular expression of VEGF and MMP-2 in vivo: Preventive effect of red wine polyphenols. J. Vasc. Res. 2008, 45, 386-394.

12. Schlachterman, A.; Valle, F.; Wall, K.M.; Azios, N.G.; Castillo, L.; Morell, L.; Washington, A.V.; Cubano, L.A.; Dharmawardhane, S.F. Combined Resveratrol, Quercetin, and Catechin Treatment Reduces Breast Tumor Growth in a Nude Mouse Model. Transl. Oncol. 2008, 1, 19-27.

13. Oak, M.H.; El Bedoui, J.; Schini-Kerth, V.B. Antiangiogenic properties of natural polyphenols from red wine and green tea. J. Nutr. Biochem. 2005, 16, 1-8.

14. Harris, D.M.; Besselink, E.; Henning, S.M.; Go, V.L.; Heber, D. Phytoestrogens induce differential estrogen receptor alpha- or beta-mediated responses in transfected breast cancer cells. Exp. Biol. Med. 2005, 230, 558-568.

15. Roussou, I.; Lambropoulos, I.; Pagoulatos, G.N.; Roussis, I.G. Decrease of heat shock protein levels in hela tumor cells by red wine extracts. Ital. J. Food Sci. 2004, 16, 381-386.

16. Lin, J.K.; Liang, Y.C.; Lin-Shiau, S.Y. Cancer Chemoprevention by Tea Polyphenols through Mitotic Signal Transduction Blockade. Biochem. Pharmacol. 1999, 58, 911-915.

17. Soleas, G.J.; Grass, L.; Josephy, P.D.; Goldberg, D.M.; Diamandis, E.P. A comparison of the anticarcinogenic properties of four red wine polyphenols. Clin. Biochem. 2002, 35, 119-124.

18. Nichenametla, S.N.; Taruscio, T.G.; Barney, D.L.; Exon, J.H. A Review of the Effects and Mechanisms of Polyphenolics in Cancer. Crit. Rev. Food Sci. 2006, 46, 161-183. 
19. Link, A.; Balaguer, F.; Goel, A. Cancer chemoprevention by dietary polyphenols: Promising role for epigenetics. Biochem. Pharmacol. 2010, 80, 1771-1792.

20. Navarro-Perán, E.; Cabezas-Herrera, J.; Campo, L.S.; Rodríguez-López, J.N. Effects of folate cycle disruption by the green tea polyphenol epigallocatechin-3-gallate. Int. J. Biochem. Cell Biol. 2007, 39, 2215-2225.

21. Yilmaz, Y.; Toledo, R.T. Major Flavonoids in Grape Seeds and Skins: Antioxidant Capacity of Catechin, Epicatechin, and Gallic Acid. J. Agric. Food. Chem. 2004, 52, 255-260.

22. Aggarwal, B.B.; Shishodia, S. Molecular targets of dietary agents for prevention and therapy of cancer. Biochem. Pharmacol. 2006, 71, 1397-1421.

23. Proestos, C.; Sereli, D.; Komaitis, M. Determination of PhC in aromatic plants by RP-HPLC and GC-MS. Food Chem. 2006, 95, 44-52.

24. Proestos, C.; Kapsokefalou, M.; Komaitis, M. Analysis of naturally occurring phenolic compounds in aromatic plants by RP-HPLC and GC-MS after silylation. J. Food Qual. 2008, 31, 402-414.

25. Lin, X.F.; Min, W.; Luo, D. Anticarcinogenic effect of ferulic acid on ultraviolet-B irradiated human keratinocyte HaCaT cells. J. Med. Plants Res. 2010, 4, 1686-1694.

26. Baskaran, N.; Manoharan, S.; Balakrishnan, S.; Pugalendhi, P. Chemopreventive potential of ferulic acid in 7,12-dimethylbenz[a]anthracene-induced mammary carcinogenesis in SpragueDawley rats. Eur. J. Pharmacol. 2010, 637, 22-29.

27. Salucci, M.; Stivala, L.A.; Maiani, G.; Bugianesi, R.; Vannini, V. Flavonoids uptake and their effect on cell cycle of human colon adenocarcinoma cells (Caco2). Br. J. Cancer 2002, 86, 1645-1651.

28. Sohi, K.K.; Mittal, N.; Hundal, M.K.; Khanduja, K.L. Gallic acid, an antioxidant, exhibits anti apoptotic potential in normal human lymphocytes: a Bcl-2 independent mechanism. J. Nutr. Sci. Vitaminol. 2003, 49, 221-227.

29. Kampa, M.; Alexaki, V.I.; Notas, G.; Nifli, A.P.; Nistikaki, A.; Hatzoglou, A.; Bakogeorgou, B.; Kouimtzoglou, E.; Blekas, G.; Boskou, D.; Gravanis, A.; Castanas, E. Antiproliferative and apoptotic effects of selective phenolic acids on T47D human breast cancer cells: Potential mechanisms of action. Breast Cancer Res. 2004, 6, 63-74.

30. Murugan, R.S.; Priyadarsini, R.V.; Ramalingam, K.; Hara, Y.; Karunagaran, D.; Nagini, S. Intrinsic apoptosis and NF- $\mathrm{BB}$ signaling are potential molecular targets for chemoprevention by black tea polyphenols in HepG2 cells in vitro and in a rat hepatocarcinogenesis model in vivo. Food Chem. Toxicol. 2010, 48, 3281-3287.

31. Way, T.D.; Lin, H.Y.; Hua, K.T.; Lee, J.C.; Li, W.H.; Lee, M.R.; Shuang, C.H.; Lin, J.K. Beneficial effects of different tea flowers against human breast cancer MCF-7 cells. Food Chem. 2009, 114, 1231-1236.

32. Lin, J.K. Cancer Chemoprevention by Tea Polyphenols through Modulating Signal Transduction Pathways. Arch. Pharm. Res. 2002, 25, 561-571.

33. Filomeni, G.; Graziani, I.; Rotilio, G.; Ciriolo, M.R. trans-Resveratrol induces apoptosis in human breast cancer cells MCF-7 by the activation of MAP kinases pathways. Genes Nutr. 2007, 2, 295-305. 
34. Yeh, C.T.; Yen, G.C. Involvement of p38 MAPK and Nrf2 in phenolic acid-induced P-form phenol sulfotransferase expression in human hepatoma HepG2 cells. Carcinogenesis 2006, 27, 1008-1017.

35. Ma, Z.C.; Hong, Q.; Wang, Y.G.; Tan, H.L.; Xiao, C.R.; Liang, Q.D.; Zhang, B.L.; Gao, Y. Ferulic acid protects human umbilical vein endothelial cells from radiation induced oxidative stress by phosphatidylinositol 3-kinase and extracellular signal-regulated kinase pathways. Biol. Pharm. Bull. 2010, 33, 29-34.

36. Maggi-Capeyron, M.F.; Ceballos, P.; Cristol, J.P.; Delbosc, S.; Le Doucen, C.; Pons, M.; Léger, C.L.; Descomps, B. Wine phenolic antioxidants inhibit AP-1 transcriptional activity. J. Agric. Food Chem. 2001, 49, 5646-5652.

37. Owuor, E.D.; Kon, A.N. Antioxidants and oxidants regulated signal transduction pathways. Biochem. Pharm. 2002, 64, 765-770.

38. Chen, Y.C.; Liang, Y.C.; Lin-Shiau, S.Y.; Ho, C.T.; Lin. J.K. Inhibition of TPA-Induced Protein Kinase $\mathrm{C}$ and Transcription Activator Protein-1 Binding Activities by Theaflavin-3,3'-digallate from Black Tea in NIH3T3 Cells. J. Agric. Food Chem. 1999, 47, 1416-1421.

39. Dhandapani, K.M.; Mahesh, V.B.; Brann, D.W. Curcumin suppresses growth and chemoresistance of human glioblastoma cells via AP-1 and NFאB transcription factors. J. Neurochem. 2007, 102, 522-538.

40. Hakimuddin, F.; Tiwari, K.; Paliyath, G.; Meckling, K. Grape and wine phenolic compounds down-regulate the expression of signal transduction genes and inhibit the growth of estrogen receptor-negative MDA-MB231 tumors in nu/nu mouse xenografts. Nutr. Res. 2008, 28, 702-713.

41. Boukamp, P.; Petrussevska, R.; Breitkreutz, D.; Hornung, J.; Markham, A. Normal keratinization in a spontaneously immortalized aneuploid keratinocyte cell line. J. Cell. Biol. 1988, 106, 761-771.

42. Mosmann, T. Rapid colorimetric assay for cellular growth and survival: Application to proliferation and cytotoxicity assays. J. Immunol. Methods 1973, 65, 53-63.

43. Lee, B.L.; Ong, C.N. Comparative analysis of tea catechins and theaflavins by highperformance liquid chromatography and capillary electrophoresis. J. Chromatogr. 2000, 881, 439-447.

Sample Availability: Samples of the compounds of interest are available from the authors.

(C) 2011 by the authors; licensee MDPI, Basel, Switzerland. This article is an open access article distributed under the terms and conditions of the Creative Commons Attribution license (http://creativecommons.org/licenses/by/3.0/). 